\title{
Green manure incorporation timing for organically grown broccoli
}

\author{
Ellen Rúbia Diniz ${ }^{(1)}$, Ricardo Henrique Silva Santos ${ }^{(1)}$, Segundo Sacramento Urquiaga ${ }^{(2)}$, \\ Luiz Alexandre Peternelli( ${ }^{(3)}$, Tatiana Pires Barrella ${ }^{(1)}$ and Gilberto Bernardo de Freitas ${ }^{(1)}$
}

\begin{abstract}
(1) Universidade Federal de Viçosa (UFV), Dep. de Fitotecnia, Av. P.H. Rolfs, s/nº, CEP 36570-000 Viçosa, MG, Brazil. E-mail: ellemrubia@bol.com.br, rsantos@ufv.br, tatibarrella@yahoo.com.br, bernardo@ufv.br (2)Embrapa Agrobiologia, Caixa Postal 74505, CEP 23890-000 Seropédica, RJ, Brazil. E-mail: urquiaga@cnpab.embrapa.br (3)UFV, Dep. de Informática. E-mail: ptrnelli@ufv.br
\end{abstract}

\begin{abstract}
The objective of this work was to determine the effect of incorporation timing of the velvet bean (Stizolobium cinereum) (GM) on both organic broccoli yield and $\mathrm{N}$ status. Mineral $\mathrm{N}$ content in the soil, biologically fixed $\mathrm{N}$ recovery by broccoli, GM biomass decomposition and $\mathrm{N}$ release kinetics were also determined. Plots were fertilized with $12 \mathrm{Mg} \mathrm{ha}^{-1}$ of organic compost and received GM either at $0,15,30$ or 45 days after transplant. Other treatments were compost (12 or $25 \mathrm{Mg} \mathrm{ha}^{-1}$ ), GM, mineral fertilizers and control (no fertilizer). The data were collected in four completely randomized blocks. GM decomposition increased mineral N content in soil as rapidly as mineral fertilizer or the supply of $25 \mathrm{Mg} \mathrm{ha}^{-1}$ of compost. The $\mathrm{N}$ half-life in GM (24 days) is smaller than the mass half-life (35 days) and the biological fixation contributed with $23.6 \%$ of $\mathrm{N}$ present in the aboveground biomass of broccoli. The result suggests a higher synchrony between the crop relative growth rate and $\mathrm{N}$ release from the GM when incorporated at crop early growth stage. The incorporation of GM until 15 days after transplanting replaces $50 \%$ of the highest compost dose, without yield loss.
\end{abstract}

Index terms: Brassica oleracea, Stizolobium cinereum, biological nitrogen fixation, decomposition rate, $\mathrm{N}$ recovery.

\section{Época de incorporação de adubo verde para o cultivo orgânico de brócolis}

\begin{abstract}
Resumo - O objetivo deste trabalho foi determinar o efeito do momento da incorporação de mucuna-cinza (Stizolobium cinereum) (AV) sobre a produtividade e o teor de $\mathrm{N}$ do brócolis orgânico. Foram determinados o teor de $\mathrm{N}$ mineral no solo, a recuperação de $\mathrm{N}$ fixado biologicamente no brócolis e a cinética de decomposição da massa e liberação de $\mathrm{N}$ do $\mathrm{AV}$. As parcelas foram fertilizadas com $12 \mathrm{Mg} \mathrm{ha}^{-1}$ de composto orgânico e receberam AV aos 0, 15, 30 e 45 dias depois do transplante. Outros tratamentos foram: composto orgânico (12 ou $25 \mathrm{Mg} \mathrm{ha}^{-1}$ ), AV, fertilizante mineral e testemunha. A decomposição do AV aumentou o teor de $\mathrm{N}$ mineral no solo tão rapidamente quanto o fertilizante mineral ou a aplicação de $25 \mathrm{Mg}$ ha $^{-1}$ de composto orgânico. A meia-vida de $\mathrm{N}$ no $\mathrm{AV}$ (24 dias) é menor que a meia-vida da massa (35 dias) e a fixação biológica contribuiu com $23,6 \%$ do $\mathrm{N}$ da parte aérea do brócolis. Os resultados sugerem maior sincronia entre a taxa de crescimento relativo da cultura e a liberação de $\mathrm{N}$ do $\mathrm{AV}$, quando incorporado no início do cultivo. A incorporação do AV até 15 dias depois do transplante substitui $50 \%$ da dose de composto sem perda de produtividade.
\end{abstract}

Termos para indexação: Brassica oleracea, Stizolobium cinereum, fixação biológica do nitrogênio, taxa de decomposição, recuperação de nitrogênio.

\section{Introduction}

Broccoli (Brassica oleracea var. italica) crop requires high supply of $\mathrm{N}$ for optimum yield (Karitonas, 2003). Organic compost application rates on horticultural crops range between 20 and $40 \mathrm{Mg} \mathrm{ha}^{-1}$ (Souza \& Resende, 2006) due both to high requirements of these crops and to low contents of nutrients, especially N. This high compost requirement is limiting to small growers. Although broccoli cultivation sequentially to cowpea resulted in seedling mortality and low yield (Schroeder et al., 1998), adjusting the management of the leguminous biomass may reduce the need for compost on organic agriculture. However, $\mathrm{N}$ supply to crops by means of $\mathrm{N}$ mineralization on green manure residue must be synchronized with crop $\mathrm{N}$ demand (Thönnissen et al., 2000a, 2000b; Cobo et al., 2002b; Murphy et al., 2004), and it is necessary that biomass addition time and crop growth rate match (Lahti \& Kuikman, 2003). 
Under tropical conditions, around $50 \%$ of green manure $\mathrm{N}$ may be mineralized within 15 days after the green manure is cut (Cobo et al., 2002a, 2000b). Most of the leguminous $\mathrm{N}$ have the soil organic matter as fate and losses may occur both by leaching (Fillery, 2001) and volatilization (Janzen \& McGinn, 1991), depending on complex variables such as the residue chemical characteristics and management, environmental conditions and developmental stage of the crop (Thönnissen et al., 2000a; Fillery, 2001; Murphy et al., 2004). Simultaneous measurements of the amounts of mineral $\mathrm{N}$ in the soil and of biomass mineralization may be an indicator of the capacity of the leguminous residues of supplying $\mathrm{N}$ to the crops (Fillery, 2001).

This work aimed to evaluate the effect of incorporation timing of velvet bean (Stizolobium cinereum) residue on organic broccoli yield and $\mathrm{N}$ status, on the mineral $\mathrm{N}$ content in the soil, and on biologically fixed $\mathrm{N}$ recovery by the broccoli crop.

\section{Material and Methods}

The work was carried out in Viçosa, MG, Brazil, $20^{\circ} 45^{\prime} \mathrm{S}$ and $42^{\circ} 51^{\prime} \mathrm{W}, 651 \mathrm{~m}$ altitude, in a loamy clay Dystric Cambisol organically cultivated over five years. The soil presented $490 \mathrm{~g} \mathrm{~kg}^{-1}$ of clay, $300 \mathrm{~g} \mathrm{~kg}^{-1}$ of silt, $80 \mathrm{~g} \mathrm{~kg}^{-1}$ of fine sand and $130 \mathrm{~g} \mathrm{~kg}^{-1}$ of coarse sand. The soil presented the following chemical characteristics $(0-20 \mathrm{~cm}): 19.4 \mathrm{~g} \mathrm{~kg}^{-1}$ of C (Walkley-Black), $\mathrm{pH}$ of 6.7; $0.0 \mathrm{cmol}_{\mathrm{c}} \mathrm{kg}^{-1}$ of $\mathrm{Al}^{3+} ; 5.9 \mathrm{cmol}_{\mathrm{c}} \mathrm{kg}^{-1}$ of $\mathrm{Ca}^{2+}$; $1.6 \mathrm{cmol}_{\mathrm{c}} \mathrm{kg}^{-1}$ of $\mathrm{Mg}^{2+} ; 350 \mathrm{mg} \mathrm{kg}^{-1}$ of $\mathrm{K}^{+}$and $146 \mathrm{mg} \mathrm{kg}^{-1}$ of $\mathrm{P}$ of soil. The mean temperature during crop growth was $19^{\circ} \mathrm{C}$.

Seeds of the Domador hybrid were sown on August 5, and transplanted on September 15, 2003. The crop was sprinkler irrigated and mechanically weeded when necessary. Harvest was carried out between November 30 and December 9, 2003. Plants received $12 \mathrm{Mg} \mathrm{ha}^{-1}$ of organic compost $(\mathrm{C})$ and green manure (GM) incorporated at broccoli seedling transplant (C12GMd0) or at 15 (C12GMd15), 30 (C12GMd30) or 45 (C12GMd45) days after transplant (DAT). Five other treatments were set up as controls: only GM applied at transplant (C0GMd0), 25 (C25) or 12 (C12) $\mathrm{Mg} \mathrm{ha}^{-1}$ of organic compost, mineral fertilizers (MF) and no fertilization (NOFERT). The broccoli experimental plot had a total area of $6.75 \mathrm{~m}^{2}$, with spacing of $0.9 \times 0.5 \mathrm{~m}$ between plants. All data were collected with four repetitions.
The organic compost was locally produced by mixing Pennisetum purpureum biomass and poultry manure. The compost presented C:N ratio 18 , total $\mathrm{N} 14.8 \mathrm{~g} \mathrm{~kg}^{-1}$, P $2.6 \mathrm{~g} \mathrm{~kg}^{-1}, \mathrm{~K}^{8} .7 \mathrm{~g} \mathrm{~kg}^{-1}, \mathrm{Ca} 12.9 \mathrm{~g} \mathrm{~kg}^{-1}$ and $\mathrm{Mg} 8.1 \mathrm{~g} \mathrm{~kg}^{-1}$. The contents are the mean of 16 samples and were determined according to methods described in Malavolta et al. (1997). The compost was manually distributed in the furrows shortly before seedling transplant.

The green manure velvet bean (Stizolobium cinereum) was cropped in a neighbor plot. Plants were cut at soil level at four months old (August 12, 2003) and the biomass was taken to the greenhouse $\left(35^{\circ} \mathrm{C}\right)$ for drying. After drying, the material was placed in nylon bags and kept in a dry and airy place until incorporation in the field. The GM biomass presented $36.2 \%$ of $\mathrm{C}$ (Walkley-Black) and $2.1 \%$ of total $\mathrm{N}$ (Kjeldahl) and the $\mathrm{C}: \mathrm{N}$ ratio was $17: 1$. GM residue was distributed over the entire experimental plot and slightly incorporated ( $5 \mathrm{~cm}$ deep) into a single dose equivalent to $8.7 \mathrm{Mg} \mathrm{ha}^{-1}$ of dry biomass (177 $\mathrm{kg} \mathrm{ha}^{-1}$ of $\mathrm{N}$ ).

As mineral fertilizer, broccoli crop received $160 \mathrm{~kg} \mathrm{ha}^{-1}$ of $\mathrm{N}$ (ammonium sulphate), $22 \mathrm{~kg} \mathrm{ha}^{-1}$ of $\mathrm{P}$ (superphosphate) and $42 \mathrm{~kg} \mathrm{ha}^{-1}$ of $\mathrm{K}$ (potassium chloride), based on recommendations of Fontes (1999). $\mathrm{N}$ fertilization was split in four applications: $20 \mathrm{~kg} \mathrm{ha}^{-1}$ $\mathrm{N}$ at transplant, and 80,30 and $30 \mathrm{~kg} \mathrm{ha}^{-1}$ of $\mathrm{N}$ applied, respectively, at 20, 40 and 60 days after transplant (DAT).

Thirty-six samples with $20 \mathrm{~g}$ of dry biomass of GM each were placed on soil surface and covered with $20 \times 40 \mathrm{~cm}$ nylon net of $4 \mathrm{~mm}^{2}$ mesh. The samples were distributed in the plots that received the C12GMd0 treatment, in four repetitions. The remaining dry matter of GM residue on each sample was collected at $0,3,7$, $12,15,20,30,45$ and 60 DAT, from September 15 to November 14, 2003. The residue samples were dried, weighted, grounded and analyzed for $\mathrm{N}$ total content by Kjeldahl method (Bremner \& Mulvaney, 1982). GM biomass decomposition and $\mathrm{N}$ release kinetics were calculated by the exponential model described by Thomas \& Asakawa (1993).

Broccoli growth was estimated by the non-destructive parameter canopy area (CA), expressed in $\mathrm{dm}^{2}$ obtained by the formulae $\mathrm{CA}=\pi \mathrm{r}^{2}$ (Santos et al., 2002). The CA measurements were carried out fortnightly based on the mean canopy radius (r), measured transversally and longitudinally to the planting line. Broccoli yield $\left(\mathrm{g} \mathrm{plant}^{-1}\right)$ was measured on four plants plot $^{-1}$ at harvest by determining the fresh biomass of the buds, cut at $2.5 \mathrm{~cm}$ 
below the last inflorescence insertion. The relative growth rate (RGR) was calculated according to Magalhães (1985), based on the canopy area measurements in the different sampling dates.

For assessing the broccoli $\mathrm{N}$ status, the last fully developed leaf at the budding initial stage was sampled and, the total $\mathrm{N}$ content was determined by the Kjeldhal method (Bremner \& Mulvaney, 1982).

The effect of GM incorporation timing on soil mineral $\mathrm{N}$ availability (0 to $15 \mathrm{~cm}$ depth) along the crop growth was assessed in all plots but the one which received only GM. Soil samples were collected before transplanting and from 7 to 60 DAT, depending on when GM was incorporated into the soil. The soil samples were kept under room conditions $\left(22^{\circ} \mathrm{C}, 85 \% \mathrm{RH}\right)$ for 18 hours and then were taken to the freezer $\left(-10^{\circ} \mathrm{C}\right)$ until analysis resume. Mineral- $\mathrm{N}$ content in the soil was defined as the sum of $\mathrm{NO}_{3}^{-}$and $\mathrm{NH}_{4}^{+}$contents. Nitrate and ammonium contents in the soil were determined, respectively, by the methods described by Yang et al. (1994) and by Kempers \& Zweers (1986).

Biological nitrogen fixation in GM and its recovery (BNF-N) by broccoli were estimated according to Shearer \& Kohl (1986), by means of the technique of natural abundance of ${ }^{15} \mathrm{~N}$. Bidens pilosa and Panicum maximum were the locally occurring, non-fixing species used as control in the technique.

The effect of GM application timing and decomposition kinetics were evaluated by analysis of polinomial regression. The models were chosen based on the significance level, the coefficient of determination, and residue analysis. Test for models identity were performed on relative growth rates equations. Comparison was carried out by nonorthogonal contrasts among the GM application dates and chosen control treatments. The Tukey test was applied for comparison among control treatments and for comparison of plant canopy area at harvest. The SAEG according to methodology of Ribeiro Júnior (2001) and the 'R' packages were used for the statistical procedures and all analysis were performed adopting $\mathrm{p} \leq 0.05$.

\section{Results and Discussion}

Broccoli yield decreased linearly with the delay of GM incorporation (Figure 1). The highest broccoli yield was attained with the $\mathrm{C} 12 \mathrm{GMd} 0$. The plants that received C12GMd15, C12GMd30 and C12GMd45, presented, respectively, 92,83 and $75 \%$ of the yield of the plants fertilized with C12GMd0.

$\mathrm{C} 25$ resulted in broccoli yield similar to that obtained with MF, but higher than the yields resulting of both $\mathrm{C} 12$ and COGMd0 and NOFERT. The supply of mineral fertilizer resulted in broccoli yield similar to those obtained with both $\mathrm{C} 12$ and C0GMd0 (Table 1).

The comparisons among incorporation timing treatments and control treatments are presented in Table 2. Both $\mathrm{C} 12 \mathrm{GMd} 0$ and $\mathrm{C} 12 \mathrm{GMd} 15$ resulted in

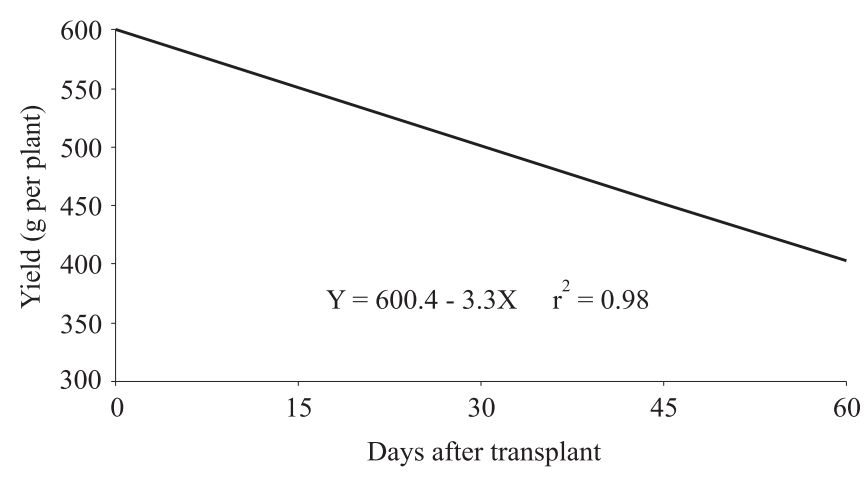

Figure 1. Organic broccoli fresh matter yield (Y) in consequence of incorporation date of green manure after broccoli transplant $(\mathrm{X})$.

Table 1. Comparisons of fresh matter yields of broccoli buds grown under the control treatments ${ }^{(1)}$.

\begin{tabular}{lc}
\hline Treatment & Yield (g per plant) \\
\hline C25 & $601.87 \mathrm{a}$ \\
MF & $525.50 \mathrm{ab}$ \\
C12 & $408.25 \mathrm{bc}$ \\
C0GMd0 & $402.18 \mathrm{bc}$ \\
NOFERT & $312.00 \mathrm{c}$ \\
\hline CV $(\%)$ & 16 \\
\hline
\end{tabular}

${ }^{(1)} \mathrm{GM} 0$ : green manure applied at transplant; $\mathrm{C} 25: 25 \mathrm{Mg} \mathrm{ha}^{-1}$ of organic compost; C12: $12 \mathrm{Mg} \mathrm{ha}^{-1}$ of organic compost; MF: mineral fertilizer; NOFERT: no fertilization; values followed by same letter are not significantly different at $\mathrm{p}>0.05$ by Tukey test.

Table 2. Comparisons of fresh matter yields of broccoli buds through contrasts with green manure timing treatments and control treatments ${ }^{(1)}$.

\begin{tabular}{lrccc}
\hline Treatment & \multicolumn{3}{c}{ Difference } & (g per plant) \\
\cline { 2 - 5 } & C12GMd0 & C12GMd15 & C12GMd30 & C12GMd45 \\
\hline C25 & $1.56^{\mathrm{ns}}$ & $-51.37^{\mathrm{ns}}$ & $-110.21^{*}$ & $-145.00^{*}$ \\
$\mathrm{C} 12$ & $195.18^{*}$ & $142.24^{*}$ & $83.41^{*}$ & 48.62 \\
$\mathrm{MF}$ & $77.93^{*}$ & $24.99^{\mathrm{ns}}$ & $-33.83^{\mathrm{ns}}$ & -68.62 \\
\hline
\end{tabular}

${ }^{(1)}$ C12GM0: $12 \mathrm{Mg} \mathrm{ha}^{-1}$ organic compost + green manure applied at transplant; C12GM15: $12 \mathrm{Mg}^{-1}$ ha $^{-1}$ organic compost + green manure incorporated at 15 DAT; C12GM30: $12 \mathrm{Mg} \mathrm{ha}^{-1}$ organic compost + green manure incorporated at $30 \mathrm{DAT}$; C12GM45: $12 \mathrm{Mg}$ ha $^{-1}$ organic compost + green manure incorporated at $45 \mathrm{DAT} ; \mathrm{C} 25: 25 \mathrm{Mg} \mathrm{ha}^{-1}$ organic compost; $\mathrm{C} 12: 12 \mathrm{Mg} \mathrm{ha}^{-1}$ organic compost; MF: mineral fertilizer. ${ }^{\text {ns }}$ No significant differences lsd (70.4). *Significant difference at $\mathrm{p} \leq 0.05$ by $\mathrm{t}$ test. 
broccoli yield similar to those obtained with $\mathrm{C} 25$, while $\mathrm{C} 12 \mathrm{GMd} 30$ and $\mathrm{C} 12 \mathrm{GMd} 45$ resulted in lower yields than those obtained with $\mathrm{C} 25$. C0GMd0 incorporation prior to 45 DAT resulted in higher broccoli yields than those obtained with C12. GM incorporation at transplant resulted in broccoli yield higher than those obtained with MF, while later incorporation resulted in similar yield than those obtained with MF.

The broccoli canopy area increased linearly until harvest in all treatments (Figure 2). At harvest, the broccoli plants that received C12GMd0 presented a canopy area $23 \%$ larger (Tukey, $p \leq 0.05$ ) than the smallest (C12GMd15 and C12GMd45), while C12GMd30 resulted in canopy areas intermediate between those ones (Figure $2 \mathrm{~A}$ ). Among the control treatments, at harvest the largest (Tukey, $\mathrm{p} \leq 0.05$ ) canopy area was obtained with supply of MF (Figure 2 B). At harvest the supply of $\mathrm{C} 25$ resulted in canopy area higher (Tukey, $\mathrm{p} \leq 0.05$ ) than the NOFERT treatment, but similar to the obtained with the supply of C0GMd0 and C12 treatments (Figure 2 B).

Plants supplied with $\mathrm{C} 12 \mathrm{GMd0}$ presented a higher relative growth rate (RGR) during the decreasing phase of this rate, after 21 DAT. RGR was similar among those plants fertilized with $\mathrm{C} 12 \mathrm{GMd} 15, \mathrm{C} 12 \mathrm{GMd} 30$ or C12GMd45 (Figure $3 \mathrm{~A}$ ). Among the control treatments, the highest maximum RGR $\left(0.144 \mathrm{dm}^{2} \mathrm{dm}^{-2}\right.$ day $\left.^{-1}\right)$

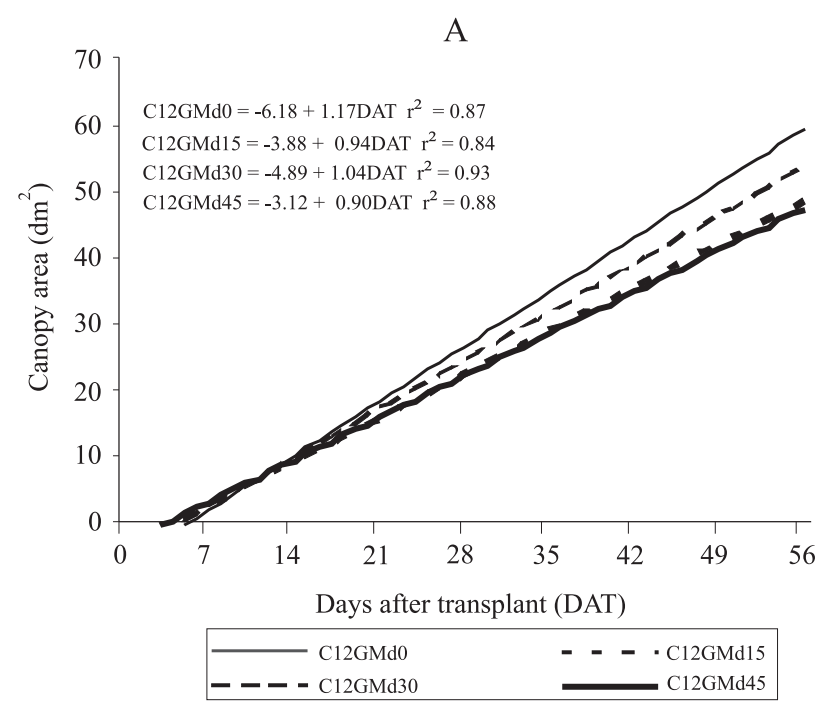

occurred at 18 DAT on plants fertilized with $\mathrm{C} 25$ or MF, while the lowest maximum RGR $\left(0.126 \mathrm{dm}^{2} \mathrm{dm}^{-2}\right.$ day $\left.^{-1}\right)$ occurred five days later on not fertilized or on plants supplied with C0GMd0, while plants supplied with C12 presented RGR intermediate between those rates (Figure $3 \mathrm{~B}$ ).

The GM biomass decomposition and $\mathrm{N}$ release kinetics are shown in Figure 4. Half-life of the GM dry biomass was of 35 days, while, at 24 days after incorporation, $50 \%$ of the initial $\mathrm{N}$ was no longer found in the GM residual biomass. At the end of 60 days, $30.5 \mathrm{~kg} \mathrm{ha}^{-1}$ of the initial $\mathrm{N}$ was still found in the GM biomass. The different treatments resulted in broccoli plants with similar $(\hat{\mathrm{y}}=3.8 \%, \mathrm{p}>0.05)$ leaf $\mathrm{N}$ content. However, the plants which received mineral fertilization presented the highest $\mathrm{N}$ content $(4.3 \%)$, and no fertilized plants, the lowest (3.3\%).

BNF accounted for $74 \%$ of the $\mathrm{N}$ present in the GM biomass. Considering the content of $2.1 \%$ of N, $1.5 \%$ of $\mathrm{N}$ present in the dry biomass of the $\mathrm{GM}$ was originated from the atmosphere, corresponding to $130 \mathrm{~kg} \mathrm{ha}^{-1}$ of $\mathrm{N}$ at the applied dose.

No significant difference ( $p>0.05$ ) was found among the contents of BNF-N recovered in the broccoli plants that received GM. In these plants, $23.6 \%$ of $\mathrm{N}$ was originated from the BNF of the incorporated GM, regardless of date of incorporation.

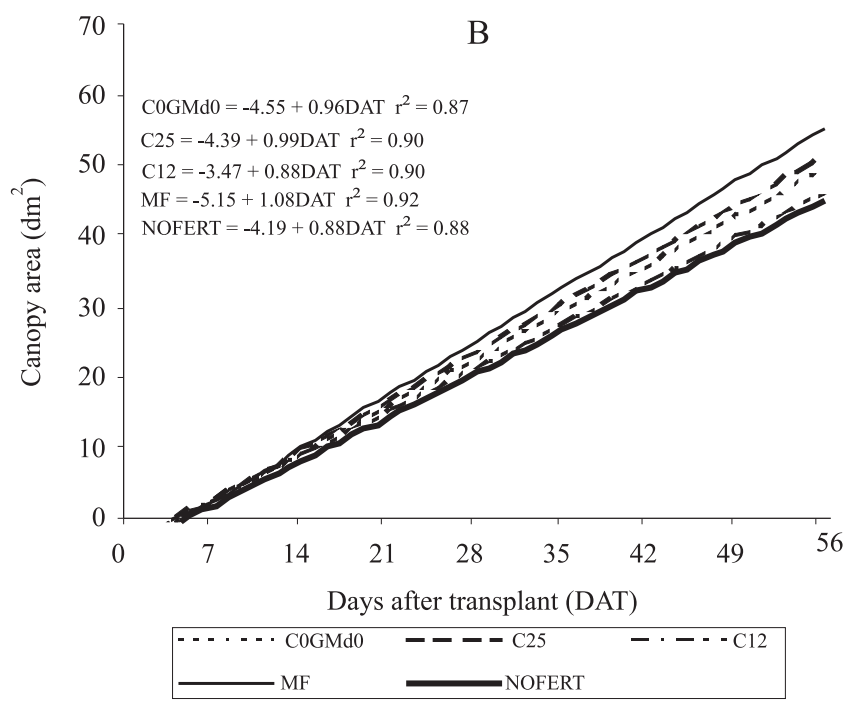

Figure 2. Performance of organic broccoli canopy area after transplant (DAT). (A) C12GMd0: $12 \mathrm{Mg} \mathrm{ha}^{-1}$ of organic compost + green manure incorporated at transplant; C12GMd15: $12 \mathrm{Mg} \mathrm{ha}^{-1}$ of organic compost + green manure incorporated at 15 DAT;

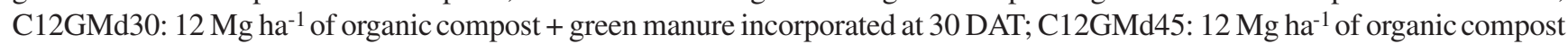
+ green manure incorporated at 45 DAT. (B) C25: $25 \mathrm{Mg} \mathrm{ha}^{-1}$ of organic compost; C12: $12 \mathrm{Mg}^{-1}$ of organic compost; MF: mineral fertilizer; COGMd0: green manure applied at transplant; NOFERT: no fertilization. 
A

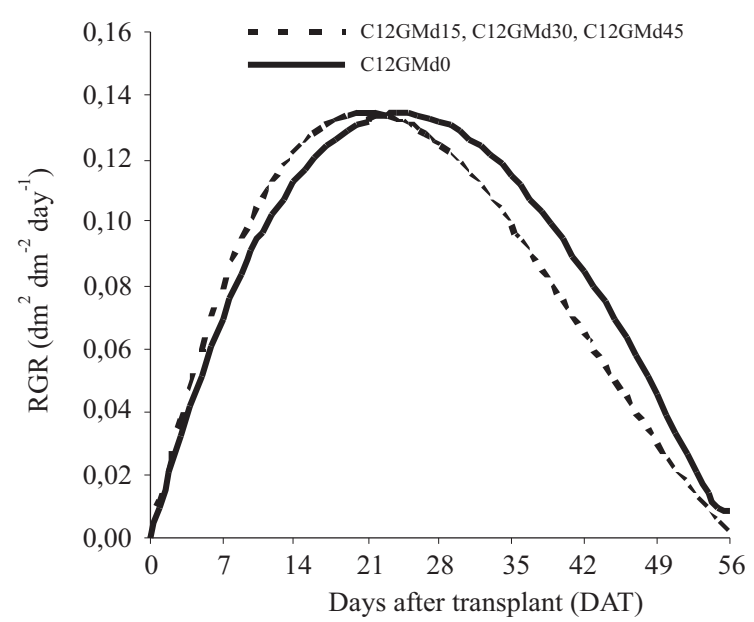

B

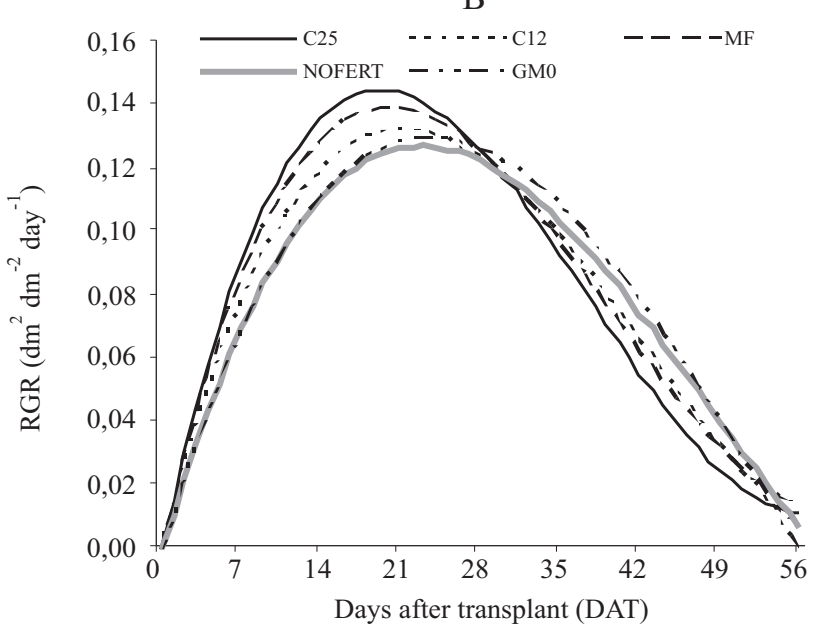

Figure 3. Performance of the relative growth rate (RGR) of the organic broccoli canopy area after transplant (DAT). (A):

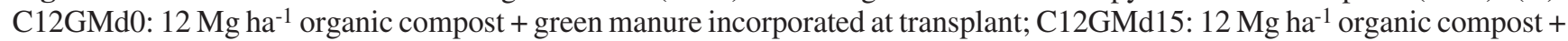
green manure incorporated at 15 DAT; C12GMd30: $12 \mathrm{Mg} \mathrm{ha}^{-1}$ organic compost + green manure incorporated at 30 DAT;

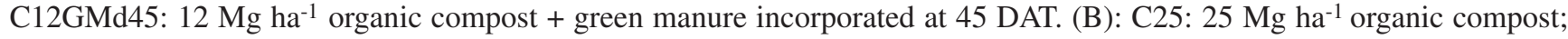
C12: $12 \mathrm{Mg} \mathrm{ha}^{-1}$ organic compost; MF: mineral fertilizer; COGMd0: green manure applied at transplant; NOFERT: no fertilization.

Mineral $\mathrm{N}$ content in the soil was affected by GM incorporation timing and other treatments (Figure 5). The mineral $\mathrm{N}$ content in the soil fertilized with only $\mathrm{C} 12$ increased up to $7 \mathrm{DAT}$, then progressively decreased and remained fairly constant after 45 DAT. At all dates, the GM incorporation resulted in a fast initial increase in soil mineral $\mathrm{N}$ availability. The $\mathrm{C} 12 \mathrm{GMd} 0$ resulted in high content of mineral $\mathrm{N}$ up to 30 days. In the plots fertilized with $\mathrm{C} 12 \mathrm{GMd} 15$, there was a decrease in the soil mineral $\mathrm{N}$ content between 7 and $15 \mathrm{DAT}$, followed by an increase up to 15 days after GM incorporation. Following the decrease in the soil mineral $\mathrm{N}$ content after 7 DAT, the $\mathrm{C} 12 \mathrm{GMd} 30$ resulted in an increase of the content of mineral $\mathrm{N}$ in the soil until $37 \mathrm{DAT}$. This content decreased again and stabilized after 45 DAT. The supply of C12GMd45 also resulted in an increase of the soil mineral $\mathrm{N}$ content for 7 days, from 45 to $52 \mathrm{DAT}$. The soil fertilized with $\mathrm{C} 25$ presented an initial high content of mineral $\mathrm{N}$, followed by a fast and then slow content decrease until harvest, while with the supply of MF, the mineral $\mathrm{N}$ content in the soil remained high up to 60 DAT, the last date evaluated.

Broccoli yields obtained from GM application added with $12 \mathrm{Mg} \mathrm{ha}^{-1}$ of organic compost, even on the later dates, were similar to those reported under tropical conditions (430 g plant $\left.^{-1}\right)$ (Trevisan et al., 2003).

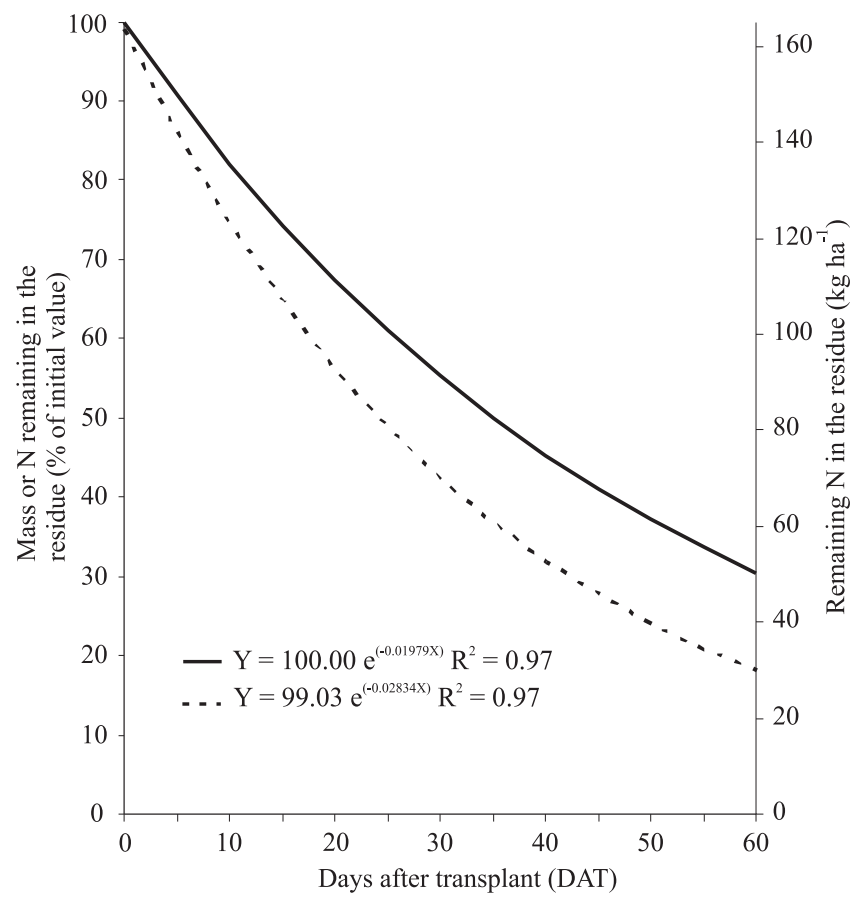

Figure 4. Dry mass decomposition (-) and N release (-----) kinetics after green manure incorporation at broccoli transplant.

Schroeder et al. (1998) incorporated cowpea crop residues before broccoli crop, aiming to reduce the amount of $\mathrm{N}$ fertilizer applied as side dressing. These authors verified that the $\mathrm{N}$ derived from GM $\left(103 \mathrm{~kg} \mathrm{ha}^{-1}\right)$ 
was not sufficient to result in higher broccoli yield, but reduced from $168 \mathrm{~kg} \mathrm{ha}^{-1}$ to $84 \mathrm{~kg} \mathrm{ha}^{-1}$ the need of $\mathrm{N}$ fertilizer supply. However, the same authors report higher plantlet mortality after transplanting, as an effect of GM incorporation. In this work, care was taken to prevent such effect by both incorporating GM residue just superficially and removing it from the plantlet stem base.

The results confirm the importance of synchronizing the date of GM biomass addition to the soil and the crop needs, as stressed by several authors (Thönnissen et al., 2000a, 2000b; Fillery, 2001; Cobo et al., 2002a; Murphy et al., 2004). The GM incorporation up to 15 DAT allows the reduction of the compost dose from 25 to $12 \mathrm{Mg} \mathrm{ha}^{-1}$ of compost, without broccoli yield losses, resulting in yields similar to that obtained with mineral fertilization. Although GM incorporation at a day next to transplanting may have reduced tomato production (Thönnissen et al., 2000b), it should be emphasized that broccoli not only requires less $\mathrm{N}$, but also has a shorter production cycle than tomato, thereby probably absorbing the released nutrients more precociously.

Broccoli yield is a result of plant growth. The supply of $\mathrm{C} 12 \mathrm{GMd} 0$ results in plants with growth similar to that of plants supplied either with MF or high compost dose. In this treatment $144 \mathrm{~kg} \mathrm{~N} \mathrm{ha}^{-1}$ were released just from the GM biomass until 60 DAT, amount which is similar to that supplied with mineral fertilizer. Later GM incorporation results in reduced plant growth, characterizing its effect in promoting growth when applied close to transplanting date. Such growth may be attributed to maintenance of higher RGR after the point of maximum relative growth in these plants, compared to the other incorporation dates.
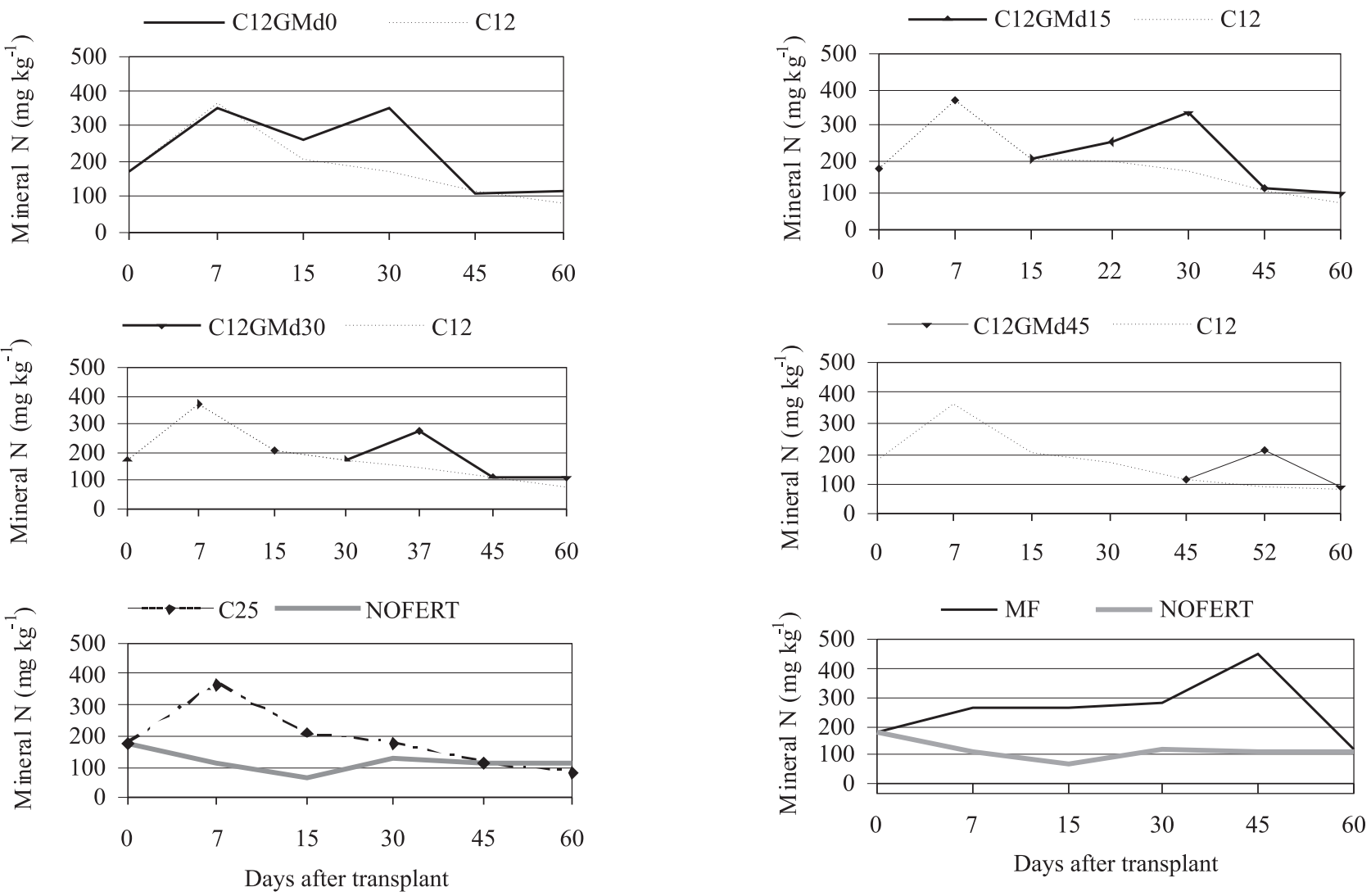

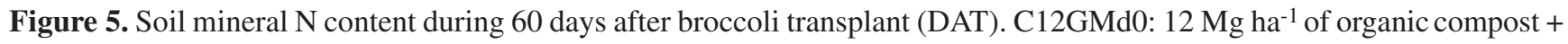
green manure applied at transplant; C12GMd15: $12 \mathrm{Mg} \mathrm{ha}^{-1}$ of organic compost + green manure applied at 15 DAT; C12GMd30: $12 \mathrm{Mg} \mathrm{ha}^{-1}$ of organic compost + green manure applied at 30 DAT; C12GMd45: $12 \mathrm{Mg} \mathrm{ha}^{-1}$ of organic compost + green manure applied at 45 DAT; C25: $25 \mathrm{Mg} \mathrm{ha}^{-1}$ of organic compost; C12: $12 \mathrm{Mg} \mathrm{ha}^{-1}$ of organic compost; MF: mineral fertilizer; NOFERT: no fertilization. 
The reference values for the optimum $\mathrm{N}$ contents in broccoli leaf tissue are between 2.6 to $3.6 \%$ (Karitonas, 2003). The contents found in the broccoli leaf at the different treatments are within the recommended ranges. Despite the differences in yield and growth, leaf $\mathrm{N}$ contents were similar among the treatments, suggesting that there are other important aspects for determining plant yield.

BNF-N recovery in broccoli plants was elevated, considering the previous results reported by Thönnissen et al. (2000b) (9-15\% in tomato) and Fillery (2001) (12-20\% in general). It should also be taken into account the BNF-N retained in the broccoli roots, not computed in the present work. Besides, the ${ }^{15} \mathrm{~N}$ released by the decomposition of the leguminous biomass may have been exchanged by the ${ }^{14} \mathrm{~N}$ present in the microbial mass, reducing the ${ }^{15} \mathrm{~N}$ recovered (Thönnissen et al., 2000a) in broccoli. The fact that it is a fast growing and highly nutrient demanding crop has certainly contributed to this result, besides the fact that incorporation, even at 45 DAT, occurred on dates close to the transplanting of the crop in the field.

Since both total N and BNF-N contents in the leaf tissues of broccoli were similar in all treatments, regardless of time of GM incorporation, yield results suggest that time of application may be as important as the amount of the nutrient supplied. The results also suggest that it is more important to supply the nutrient when the broccoli plant presents high relative growth rates, from 7 to 41 DAT, than when it presents greater dry mass accumulation. In this work the $\mathrm{N}$ release from GM biomass increased from $33 \mathrm{~kg} \mathrm{ha}^{-1}$ (7 DAT) to $122 \mathrm{~kg} \mathrm{ha}^{-1}$ (41 DAT).

Shelp \& Liu (1992) report that leaf N concentration in broccoli was higher between 14 and 22 days after transplanting, decreasing with plant growth. In this work, during this period, the highest mineral $\mathrm{N}$ contents in soil were provided by incorporating the GM biomass until 15 DAT. In this period, despite the plants presenting small size, growth differences were already verified. Thus, $\mathrm{N}$ availability in soil at the initial broccoli growth phase seems to be crucial for the results obtained, and earlier incorporation of GM, added with half dose of organic compost, was able to provide such availability.

There was a rapid increase of the mineral $\mathrm{N}$ contents in the soil after GM mineralization. This result was probably due to the characteristics of low $\mathrm{C}: \mathrm{N}$ ratio and high $\mathrm{N}$ content of the GM biomass, associated with the experimental conditions of irrigation, high temperatures and vegetal biomass incorporation, greatly favouring GM decomposition rate and extension and subsequent $\mathrm{N}$ release (Janzen \& McGinn, 1991; Fillery, 2001; Murphy et al., 2004).

In the control-treatments, between 14 and 22 DAT, the variations in mineral $\mathrm{N}$ contents may account not only for the initial RGR differences but also for the differences in broccoli yield. The MF and the supply of C25 resulted in high contents of mineral $\mathrm{N}$ in the soil, helping to explain both the highest RGRs and yields. The soil mineral N content peak at 45 DAT with MF supply is probably due to ammonium sulphate side dressing at 40 DAT, shortly before sampling. The result suggests that GM may be a promising tool of biologically improving $\mathrm{N}$ balance in high $\mathrm{N}$ demanding horticultural crops.

\section{Conclusions}

1. In organic broccoli cultivation under tropical conditions, the incorporation of velvet bean biomass up to 15 days after transplanting reduces organic compost needs from 25 to $12 \mathrm{Mg} \mathrm{ha}^{-1}$, without yield loss.

2. The fast $\mathrm{N}$ mineralization from $\mathrm{GM}$ residue leads to an elevation of mineral $\mathrm{N}$ content in the soil in close synchronicity with plant requirements.

3. Biological nitrogen fixation provided $24 \%$ of the $\mathrm{N}$ present on the aboveground biomass of organically cultivated broccoli.

\section{Acknowledgement}

To CNPq and Capes, for the financial support.

\section{References}

BREMNER, J.M.; MULVANEY, C.S. Nitrogen total. In: PAGE, A.L. (Ed.). Methods of soil analysis. $2^{\text {nd }}$ ed. Madison: Soil Science Society of America, 1982. p.595-624.

COBO, J.G.; BARRIOS, E.; KASS, D.C.L.; THOMAS, R.J. Decomposition and nutrient release by green manures in a tropical hillside agroecosystem. Plant and Soil, v.240, p.331-342, 2002a.

COBO, J.G.; BARRIOS, E.; KASS, D.C.L.; THOMAS, R. Nitrogen mineralization and crop uptake from surface-applied leaves of green manure species on a tropical volcanic-ash soil. Biology and Fertility of Soils, v.36, p.87-92, 2002b.

FILLERY, I.R.P. The fate of biologically fixed nitrogen in legumebased dryland farming system: a review. Australian Journal of Experimental Agriculture, v.41, p.361-381, 2001.

FONTES, P.C.R. Brócolos. In: RIBEIRO, A.C.; GUIMARÃES, P.T.G.; ALVAREZ VENEGAS, V.H. (Ed.). Recomendações para o uso de corretivos e fertilizantes em Minas Gerais: 
5aa aproximação. Viçosa: Comissão de Fertilidade do Solo do Estado de Minas Gerais, 1999. p.183.

JANZEN, H.H.; McGINN, S.M. Volatile loss of nitrogen during decomposition of legume green manure. Soil Biology and Biochemistry, v.23, p.291-297, 1991.

KARITONAS, R. Development of a nitrogen management tool for broccoli. Acta Horticulturae, v.627, p.125-129, 2003.

KEMPERS, A.J.; ZWEERS, A. Ammonium determination in soil extracts by the salicylate method. Soil Science and Plant Analysis, v.17, p.715-723, 1986.

LAHTI, T.; KUIKMAN, P.J. The effect of delaying incorporation of green manure crop on $\mathrm{N}$ mineralization and spring wheat (Triticum aestivum L.) performance. Nutrient Cycling in Agroecosystems, v.65, p.265-280, 2003.

MAGALHÃES, A.C.N. Análise quantitativa do crescimento. In: FERRI, M.G. Fisiologia vegetal. 2.ed. São Paulo: Edusp, 1985. v.1, p.333-350.

MALAVOLTA, E.; VITTI, G.C.; OLIVEIRA, S.A. Avaliação do estado nutricional das plantas: princípios e aplicações. 2.ed. Piracicaba: Potafos, 1997. 319p.

MURPHY, D.V.; STOCKDALE, E.A.; HOYLE, F.C.; SMITH, J.U.; FILLERY, I.R.P.; MILTON, N.; COOKSON, W.R.; BRUSSAARD, L.; JONES, D.L. Matching supply with demand. In: HATCH, D.J.; CHADWICK, D.R.; JARVIS, S.C.; ROKER, J.A. (Ed.). Controlling nitrogen: flows and losses. Wageningen: Wageningen Academic Pub., 2004. p.101-112.

RIBEIRO JÚNIOR, J.I. Análises estatísticas no SAEG. Viçosa: UFV, 2001. 301p.

SANTOS, R.H.S.; GLIESSMAN, S.R.; CECON, P.R. Crop interactions in broccoli intercropping. Biological Agriculture and Horticulture, v.20, p.51-75, 2002.
SCHROEDER, J.L.; KAHN, B.A.; LYND, J.Q. Utilization of cowpea crop residues to reduce fertilizer nitrogen inputs with fall broccoli. Crop Science, v.38, p.741-749, 1998.

SHEARER, G; KOHL, D.H. $\mathrm{N}_{2}$-fixation in field settings: estimations based on natural ${ }_{15} \mathrm{~N}$ abundance. Australian Journal of Plant Physiology, v.13, p.699-756, 1986.

SHELP, B.J.; LIU, L. Nutrient uptake by field-grown broccoli and net nutrient mobilization during inflorescence development. Plant and Soil, v.140, p.51-155, 1992.

SOUZA, J.L. de; RESENDE, P.L. Manual de horticultura orgânica. 2.ed. Viçosa: Aprenda Fácil, 2006. 843p.

THOMAS, R.J.; ASAKAWA, N.M. Decomposition of leaf litter tropical forage grasses and legumes. Soil Biology and Biochemistry, v.25, p.1351-1361, 1993.

THÖNNISSEN, C.; MIDMORE, D.J.; LADHA, J.K.; SCHMIDHALTER, U. Legume decomposition and nitrogen release when applied as green manures to tropical vegetable production systems. Agronomy Journal, v.92, p.253-260, 2000a.

THÖNNISSEN, C.; MIDMORE, D.J.; LADHA, J.K.; SCHMIDHALTER, U. Tomato crop response to short-duration legume green manures in tropical vegetable systems. Agronomy Journal, v.92, p.245-253, 2000b.

TREVISAN, J.N.; MARTINS, G.A.K.; LÚCIO, A.D.; CASTAMAN, C.; MARION, R.R.; TREVISAN, B.G. Rendimento de cultivares de brócolis semeadas em outubro na região centro do Rio Grande do Sul. Ciência Rural, v.33, p.233-239, 2003.

YANG, J.E.; SKOGLEY, E.O.; SCHAFF, B.E.A. Simple spectrophotometric determination of nitrate in water, resin, and soil extracts. Soil Science Society of America Journal, v.62, p.1108$1115,1994$.

Received on January 31, 2006 and accepted on October 31, 2006 